\title{
EDITORIAL
}

\section{CIVIL-MILITARY RELATIONS}

This is the title of this year's first issue, and civil-military relations will be the guiding theme of the following three issues planned for this year. In the second issue we would like to know what is new in the development of the defence system, while we want to dedicate the third one to the emerging non-military threats, which appear in the form of cyber threats, various diseases, such as Ebola, and of course as the problem of increased migration from Africa towards European borders. In the fourth issue, we will remember the centenary of the beginning of the Isonzo Front.

Civil-military relations denote a relationship between the civil society and military organizations. When looking at them in more detail, we find that it is a form of control over the military organization by the civil society. The first two authors to focus on these relationships were Sun Tzu around 500 BC and Carl von Clausewitz on the transition from the $17^{\text {th }}$ to the $18^{\text {th }}$ century. They based their findings on the fact that the military are in the service of the state. Civil-military relations were introduced into the academic sphere of political science and sociology by Samual P. Huntington and Morris Janowitz. Much of the literature discussing this topic emerged in the period between the end of World War II and the fall of the Berlin Wall. The transformation of armed forces as a result of the end of the bloc division in the western part of the world has contributed to the emergence of a variety of literature focusing on the transformation paradigm primarily developed within NATO.

We can conclude that, after 2010 in Slovenia, the scope of military professional and scientific literature has been regressing. Despite the large amount of security, defence and military challenges, there is no real motivation in academic and professional circles to organize events where one would exchange ideas and critical thoughts and respond to them. Due to the lack of such additional incentives, it seems somewhat logical that there are also no articles, monographs and textbooks dealing with these topics. 
What can we do to encourage debate on civil-military relations, security, defence and military, in order to produce high-quality writing for others - students, youth, veterans, professional and scientific public, civil society?

One of the options available to the Slovenian Armed Forces and the General Staff of the Slovenian Armed Forces as the authority issuing this publication is to encourage the employees and those who work with the armed forces and ministries to write. The result of such incentives are the articles published in this issue.

Gregor Garb wrote an article titled Establishment of private military companies through a prism of global security, basing his findings on the changes in the political and security environment. This has led to the fact that, in addition to the traditional ones, non-state actors with transnational connections and influences were being mentioned in professional security circles. This subject was discussed by Professor Žabkar as early as in 2004 in the chapter Have the first years of the third millennium led to the privatization of the military profession, published in the second volume of the book titled Marsova dediščina (Mars's heritage). A good ten years later, Garb is presenting his findings.

Padányi József and László Földi present different experiences of the Hungarian Armed Forces in international operations and missions as well as its assistance to the population in the event of natural and other disasters. In 2010, the Hungarian Armed Forces assisted in the aftermath a major disaster of the red-sludge spill. More on this subject can be found in the article Tasks and experiences of the Hungarian Defence Forces in crisis management.

Late last year, the Alliance ended the ISAF operation in Afghanistan, where members of the Slovenian Armed Forces worked with the Allied forces for ten years. Kristian Beršnak wrote an article on the mission, tasks and experiences of the Special Operations Unit titled Development of $S A F$ special forces and experiences from Afganistan.

Addressing today's challenges determines the use of a wide spectrum of civil and military capabilities, improved cooperation and coordination between all the entities involved and the creation of one single entity of national security, writes Andrej Androjna in his article titled Coastguard - factor of enhancing security in maritime transport, where he examines different options of providing this form of security.

In his article Usefulness of Topobase software in property management of the defence sector, Andrej Skvarča describes a software tool used by the Cerklje ob Krki airport. In the time when the protection of critical infrastructure is becoming increasingly important, it seems reasonable to use this software tool more widely in the defence system. 
This was the amount of engagement provided for this issue by the Slovenian Armed Forces. Is there maybe anybody else who deals with defence and military issues? There are some faculties in Slovenia with chairs dealing with different security topics. There are some institutions which can be referred to as "think tanks", the term used in an English-speaking environment to denote the institutions renowned as "brain centres" of new ideas.

Are we in Slovenia out of new ideas concerning security? Perhaps they are still there, but have remained caught somewhere "on air", because nobody writes them in a professional or scientific article. 